\title{
The Development of a Live Air Cleaner as Indoor Garden for an Unventilated Air Conditioned Room
}

\author{
Prasasto Satwiko1, YP Suhodo', Israni \\ Silvia S, A Djoko Istiadji ${ }^{1}$, Nimas \\ Sekarlangit ${ }^{1}$, Dewi Retnaningati ${ }^{2}$
}

${ }^{1}$ Faculty of Engineering, Universitas Atma Jaya Yogyakarta, Indonesia

${ }^{2}$ Faculty of Technobiology, Universitas Atma Jaya Yogyakarta, Indonesia

\author{
Article History \\ Received : 03 March 2020 \\ Accepted : 29 March 2020 \\ Published : 24 April 2020
}

\begin{abstract}
Urban temperatures continue to increase due to urban heat island and global warming. Air temperatures in warm, humid tropical cities have exceeded $32^{\circ} \mathrm{C}$. To achieve thermal comfort in buildings, people adopted air conditioners (ACs) that can consume more than $40 \%$ of the building's electrical energy. Air conditioning is often not accompanied by a supply of fresh outdoor air to minimize heat gain from the warm outdoor air. In that unventilated room, the $\mathrm{CO}_{2}$ concentration easily exceeds $1,000 \mathrm{ppm}$ and causes discomfort. Plants such as Dracaena sanderiana require $\mathrm{CO}_{2}$ for photosynthesis. At the same time, they produce $\mathrm{O}_{2}$. Dracaena sanderiana has the potential to keep $\mathrm{CO}_{2}$ concentrations in the room for not exceeding the comfort limit. That plant can be integrated into architectural elements, both interior and exterior (combined with windows or facades), in the form of a "living air purifier" or Live Air Cleaner (LAC). This research developed a LAC in the form of an interior garden that can be used as an interior architectural element. The application of LAC helps to save the electrical energy of unventilated air-conditioned rooms while preventing the room $\mathrm{CO}_{2}$ concentration from reaching the maximum limit of indoor $\mathrm{CO}_{2}$ level acceptable to humans. The research adopted experimental methods using three experiment chambers to measure the Dracaena sanderiana's $\mathrm{CO}_{2}$ absorption efficiency. The experiments found that Dracaena sanderiana had a unique performance, which should be considered when it is used as a live air cleaner. Though this plant absorbs $\mathrm{CO}_{2}$, its efficiency is low. Sufficient volume of Dracaena sanderiana is needed if it is to reduce indoor $\mathrm{CO}_{2}$ concentration.
\end{abstract}

Keywords: Live Air Cleaner, Air conditioning, Indoor garden, $\mathrm{CO}_{2}$ absorption

\section{Introduction}

Urban indoor air quality (IAQ) is a global problem as a metropolitan population spends $90 \%$ of its life indoor (Tarran et al., 2007). Modern countries prioritize IAQ because it can affect human health and productivity (Suhaimi et al., 2017). Air conditioning in urban buildings has two main objectives, namely temperature control and air refreshment. For the second purpose, the level of refreshment with outdoor

Correspondence: Prasasto Satwiko

Faculty of Engineering, Universitas Atma Jaya

Yogyakarta, Indonesia

E-mail: prasasto.satwiko@uajy.ac.id air is usually in the range of $11-15 \%$ per hour and tends to produce higher levels of air pollution in the room than outside (Burchett, 2009). Indoor $\mathrm{CO}_{2}$ levels are, in general, higher than outdoor because of the occupants (Burchett et al., 2008). Air composed of $21 \%$ $\mathrm{O}_{2}$ and $0.033 \% \mathrm{CO}_{2}$ taken in by people from the healthy air becomes $16-17 \% \mathrm{O}_{2}$ and $4 \%$ $\mathrm{CO}_{2}$ content during discharge from the lungs. This change leads to a rapid rise in $\mathrm{CO}_{2}$ content in the environment (Bulgurcu et al., 2006). Increased levels of $\mathrm{CO}_{2}$ cause loss of concentration and drowsiness faster than the depletion of $\mathrm{O}_{2}$ (Burchett, 2009). According to ASHRAE, the recommended level of indoor $\mathrm{CO}_{2}$ is $1,000 \mathrm{ppm}$ as the maximum indoor air concentration acceptable to humans (Stanke 
et al., 2010). Some organizations (such as UTS) choose $\mathrm{CO}_{2}$ levels of $800 \mathrm{ppm}$ as the maximum trigger for extra ventilation (Burchett, 2009). Various efforts have been made to ensure that IAQ sustainability is guaranteed. Temperatures in humid tropical cities have exceeded $32^{\circ} \mathrm{C}$. To achieve thermal comfort in buildings, people use air conditioners $(\mathrm{AC})$ that can consume more than $40 \%$ of the building's electrical energy. Air conditioning is often not accompanied by a supply of fresh outdoor air to minimize heat gain.

Researchers found that indoor plants can reduce indoor air pollution. Generally, plants, carbon dioxide $\left(\mathrm{CO}_{2}\right)$, light, and temperature are involved in photosynthesis (Suhaimi, et al, 2017). Indoor plants consume carbon dioxide and produce oxygen through photosynthesis (Cetin, 2015). Indoor plants have been shown to eliminate most types of airborne pollutants that arise from both outside and indoor sources (Tarran et al., 2007). Plants can absorb air pollution, and offer coolness and shade. Besides, spending half an hour in the park can lower blood pressure, reduce anxiety and anger, and provide a feeling of calm and pleasure (Burchett et al., 2008; Wood et al., 2010). Indoor plants are one of the botanicals that can act as bio-filtration. Bio-filtration is the filtration and metabolic breakdown of contaminant compounds, usually in soil or water, but also indoor air (Llewellyn and Dixon, 2011). Biofilters are bioreactors in which contaminated air or water flows pass through areas with a high biological activity where contaminants are neutralized by biological processes (Soreanu et al., 2013).

\section{Method}

This research used experimental methods that followed a set of scenarios (Table I, II, and III). Three experiment chambers, namely $E C 1, E C 2$, and EC3 with their dimensions of $0.3 \times 0.3 \times 0.7 \mathrm{~m}^{3}, \quad 1.0 \times 1.0 \times 1.0 \mathrm{~m}^{3}$, and $2.4 \times 2.4 \times 2.4 \mathrm{~m}^{3}$, were used. A split type air conditioner, a TCL $0.5 \mathrm{HP}$, was used to maintain the EC's air temperature at $24^{\circ} \mathrm{C}$. The concentration of $\mathrm{CO}_{2}$ and $\mathrm{O}_{2}$ inside ECs were measured and recorded by, consecutively, Combo IAQ Meter 77597 and Lutron DO-5510. Hobo data logger was also used to record the outdoor and indoor environment, which included air temperature and air humidity.

Two plant lamps, LED 25W E27 AC85-265V, were used to generate photosynthesis when sunlight was absent. $\mathrm{CO}_{2}$ was added to $\mathrm{EC}$ by burning $20 \mathrm{ml}$ of spirits (methylated spirits) at the beginning of each scenario. Each scenario was last for 12-48 hours, during which the changes in the concentration of $\mathrm{CO}_{2}$ were recorded. Each scenario was repeated three times to get the averaged results. The scenario of the experiments was made mainly to find the optimum performance of the Dracaena sanderiana (Lucky Bamboo) in absorbing $\mathrm{CO}_{2}$.

Table 1. Scenario For EC1

\begin{tabular}{|c|c|c|c|c|}
\hline Plant & $\begin{array}{c}\mathrm{CO}_{2} \\
\text { Source }\end{array}$ & Time & Light & $\begin{array}{c}\text { Scenario } \\
\text { (E) }\end{array}$ \\
\hline \multirow{4}{*}{$\begin{array}{c}\text { Dracaena } \\
\text { sanderiana } \\
\text { (Lucky } \\
\text { Bamboo) }\end{array}$} & $\begin{array}{c}\text { Ambient } \\
\text { air }\end{array}$ & 24 hours & $\begin{array}{l}\text { Sun (Fig. 1) } \\
\text { without LED } \\
\text { plant lamp } \\
\text { (Fig. 2) }\end{array}$ & 1 \\
\hline & $\begin{array}{c}\text { Ambient } \\
\text { air }\end{array}$ & $\begin{array}{c}12 \text { hours } \\
\text { (night } \\
\text { time) }\end{array}$ & $\begin{array}{l}\text { LED plant lamp } \\
\text { (Fig. } 3)\end{array}$ & 2 \\
\hline & \multirow[b]{2}{*}{$\begin{array}{l}\text { Ambient } \\
\text { air }\end{array}$} & & Sun (Fig. 1) & \multirow[b]{2}{*}{3} \\
\hline & & 24 hours & $\begin{array}{l}\text { LED plant lamp } \\
\text { (Fig. 3) }\end{array}$ & \\
\hline
\end{tabular}

Figure 1. Dracaena sanderiana in EC1 with sunlight

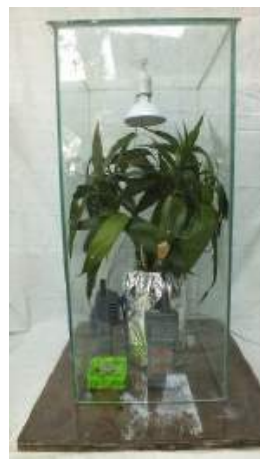

Figure 2. Dracaena sanderiana in EC1 at night without an LED plant lamp

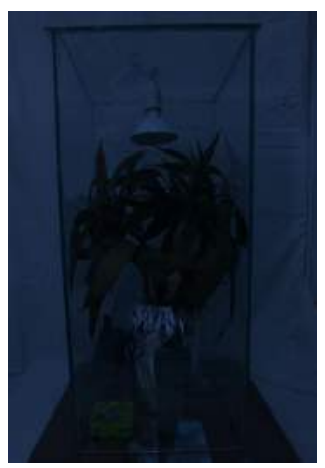

Figure 3. Dracaena sanderiana in EC1 at night with an LED plant lamp

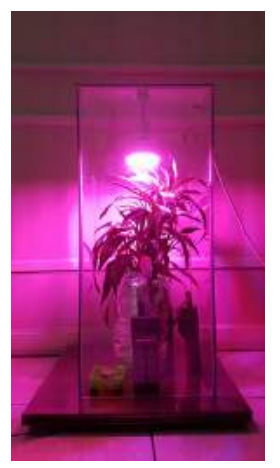


Journal of Architectural Research and Design Studies Volume 4 Number 1 April 2020

47

Table 2. Scenario for EC2

\begin{tabular}{|c|c|c|c|c|}
\hline Plant & $\begin{array}{c}\mathrm{CO}_{2} \\
\text { Source }\end{array}$ & Time & Light & $\begin{array}{c}\text { Scenario } \\
\text { (E) }\end{array}$ \\
\hline \multirow{6}{*}{ 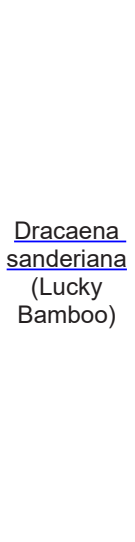 } & $\begin{array}{l}\text { Ambient } \\
\text { air }\end{array}$ & $\begin{array}{c}24 \text { hours } \\
\text { (1 pot) }\end{array}$ & $\begin{array}{l}\text { Sun (Fig. 4) } \\
\text { LED plant lamp } \\
\text { (Fig. 5) }\end{array}$ & 4 \\
\hline & $\begin{array}{c}\text { Ambient } \\
\text { air }\end{array}$ & $\begin{array}{l}24 \text { hours } \\
\text { (6 pots) }\end{array}$ & $\begin{array}{c}\text { Sun (Fig. 6) } \\
\text { LED plant lamp }\end{array}$ & 5 \\
\hline & \multirow[t]{2}{*}{$\begin{array}{l}\text { Ambient } \\
\text { air }\end{array}$} & $\begin{array}{l}48 \text { hours } \\
\text { (6 pots) }\end{array}$ & $\begin{array}{c}\text { Sun (Fig. 6) } \\
\text { Without the LED } \\
\text { plant lamp (Fig. 7) }\end{array}$ & 6 \\
\hline & & \multirow{3}{*}{$\begin{array}{l}48 \text { hours } \\
\text { (6 pots) }\end{array}$} & Sun (Fig. 6) & \multirow{3}{*}{7} \\
\hline & \multirow{2}{*}{$\begin{array}{c}\text { Ambient } \\
\text { air }\end{array}$} & & $\begin{array}{l}\text { LED plant lamp (1 } 1^{\text {st }} \\
\text { night) (Fig. } 8)\end{array}$ & \\
\hline & & & $\begin{array}{l}\text { Without the LED } \\
\text { plant lamp }\left(2^{\text {nd }}\right. \\
\text { night })(\text { Fig. } 7)\end{array}$ & \\
\hline
\end{tabular}

Figure 4. Dracaena sanderiana (1 pot) in EC2 with sunlight

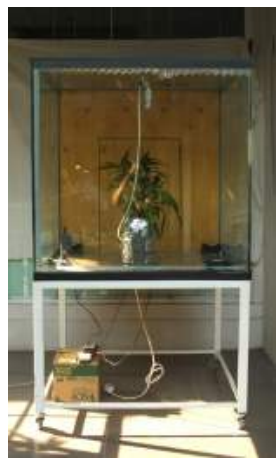

Figure 5. Dracaena

sanderiana (1 pot) in Figure 6. Dracaena EC2 in the night with sanderiana (6 pots) in LED plant lamp EC2 with sunlight
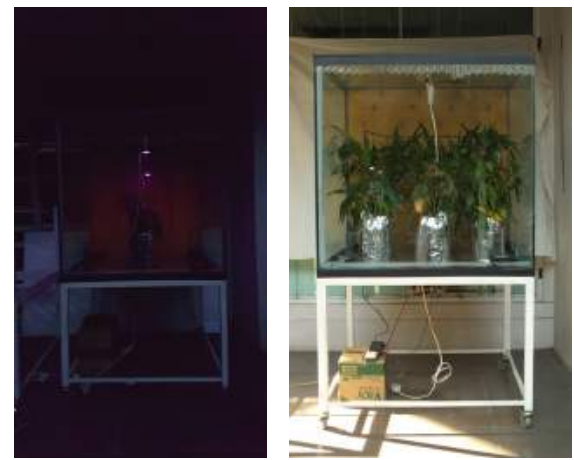

Figure 7. Dracaena Figure 8. Dracaena sanderiana (6 pots) in sanderiana (6 pots) in EC2 in the night without EC2 in the night with LED plant lamp LED plant lamp
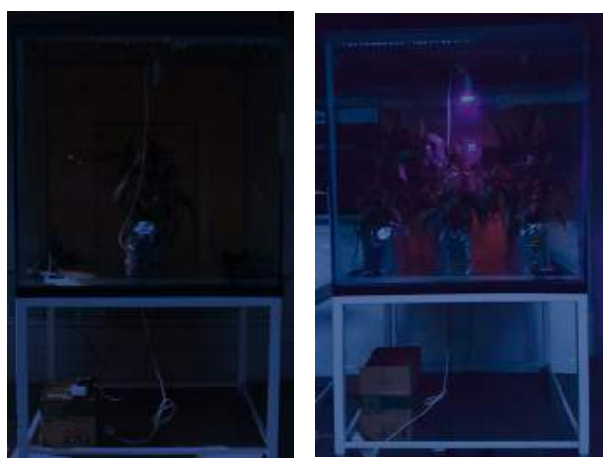

Table 3. Scenario EC3

\begin{tabular}{ccccc}
\hline Plant & $\begin{array}{c}\mathrm{CO}_{2} \\
\text { Source }\end{array}$ & Light & Plant Position & $\begin{array}{c}\text { Scenario } \\
\text { (E) }\end{array}$ \\
\hline $\begin{array}{cccc}\text { Dracaena } \\
\frac{\text { sanderiana }}{\text { (Lucky }}\end{array}$ & $\begin{array}{c}\text { Spirits } \\
(20 \mathrm{ml})\end{array}$ & sun & west window & 8 \\
Bamboo) & 2 Humans & sun & north window & 9 \\
& & & north window & 11 \\
\hline
\end{tabular}

Figure 9. Dracaena sanderiana (6 pots) in EC3 with sunlight west window

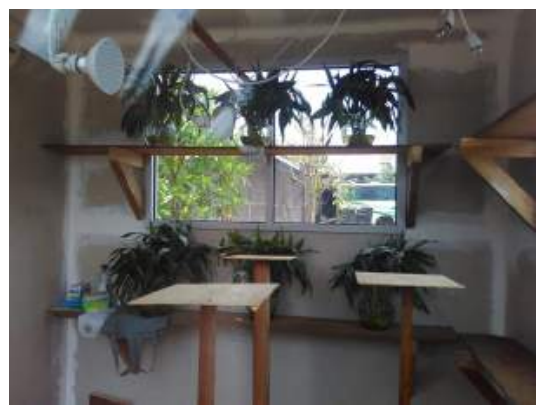

Fig. 10. Dracaena sanderiana (6 pots) in EC3 with sunlight north window

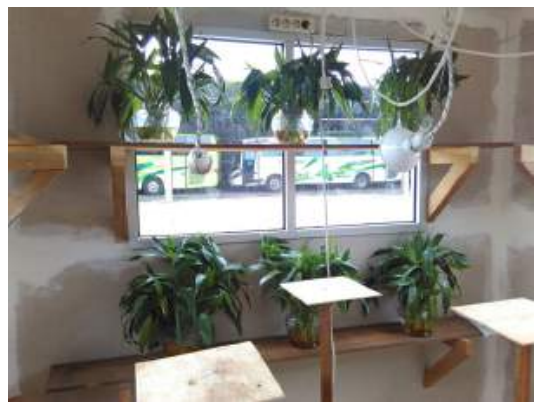

\section{Result and Discussion}

Five to eight hours of experiments by Sue found a decrease in $\mathrm{CO}_{2}$ concentration by various plants (Suhaimi, et al, 2017). Reductions of $\mathrm{CO}_{2}$ from $1000 \pm 10 \mathrm{ppm}$ were $71.67 \mathrm{ppm}$ (Prayer Plant), 66.67 ppm (Syngonium), 64.60 ppm (Fern Kadaka), 60.67 ppm (Golden Pothos) ), 55.4 ppm (Dumb Cane), and 23.67 ppm (Anthurium). Other studies have shown that 189 Bird's-Nest Fern pots can reduce $\mathrm{CO}_{2}$ concentrations from $2000 \mathrm{ppm}$ to $1000 \mathrm{ppm}$ in 2 hours 6 minutes and to $600 \mathrm{ppm}$ in 5 hours 37 minutes (Su, 2014). In the same period, we experimented in EC3 using Dracaena sanderiana for 4 hours. Plants were placed on the edge of the window exposed to direct sunlight. In the first 2 hours, the plants were placed in the northern window, and the next 2 hours were placed in the western window. The source of $\mathrm{CO}_{2}$ was $20 \mathrm{ml}$ of spirits. A fan 
The Development of a Live Air Cleaner as Indoor Garden for an Unventilated Air Conditioned Room Prasasto Satwiko, YP Suhodo, Israni Silvia S, A Djoko Istiadji, Nimas Sekarlangit, Dewi Retnaningati

facing directly to the plant was used. An AC maintained the air temperature at $24^{\circ} \mathrm{C}$.

Figure 11. $\mathrm{CO}_{2}$ concentration on $\mathrm{EC} 3$, facing north

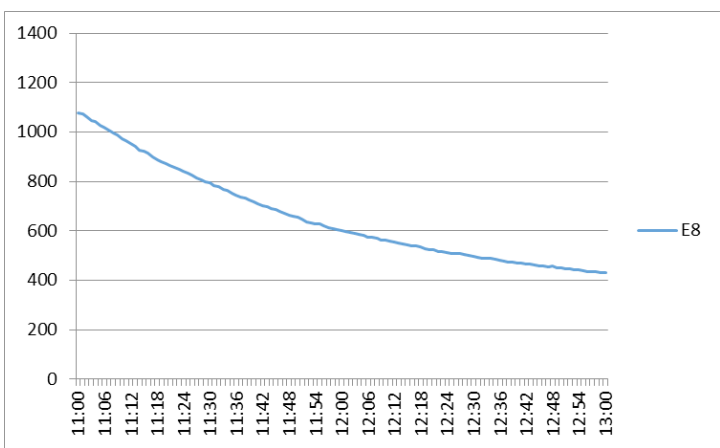

Figure 12. $\mathrm{CO}_{2}$ level on $\mathrm{EC} 3$, facing west

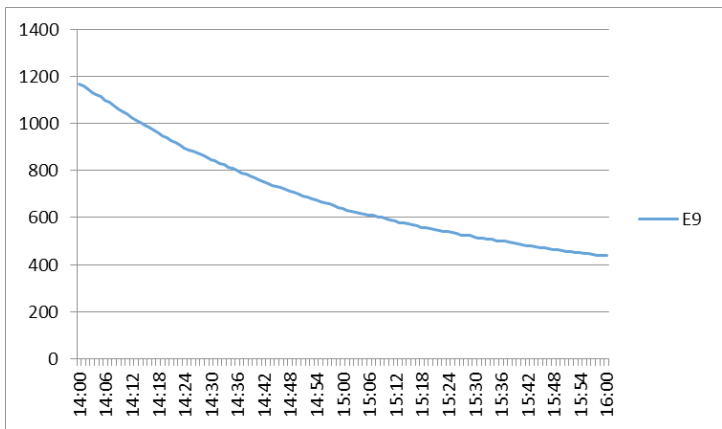

Figures 11 and 12 show that Dracaena sanderiana reduced $\mathrm{CO}_{2}$ concentration by 600 $700 \mathrm{ppm}$ within two hours. It is because plants carry out photosynthetic processes actively when directly exposed to the sun. However, the amount of $\mathrm{CO}_{2}$ reduction changed when the experiment was carried out for 24 hours and 48 hours.

The experiment without $\mathrm{CO}_{2}$ from ambient air was carried out in EC1 in three stages and used outdoor air. The first experiment (E1) lasted for 24 hours and used sunlight during the day but without any plant lamp at night. The second experiment (E2) lasted for 12 hours and used plant lamps at night. The third experiment (E3) lasted for 24 hours and used sunlight during the day, plant lamps at night (Fig. 13).
Figure 13. EC1 result

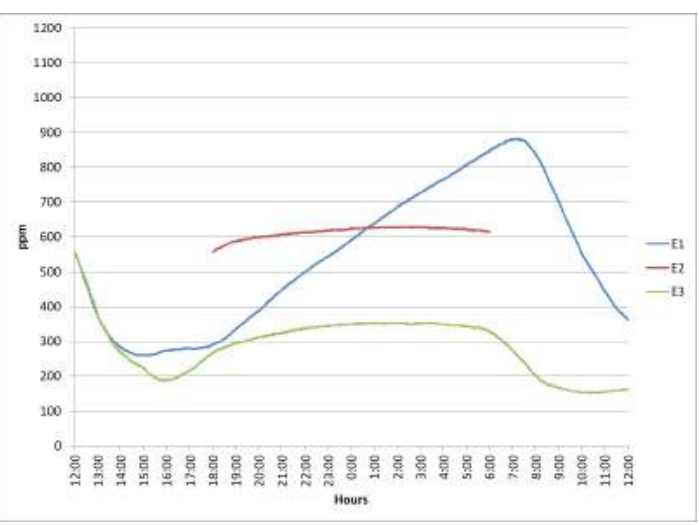

Note:

E1: 24 hours, without plant lamps.

E2: 12 hours, with a plant lamp (at night).

E3: 24 hours, without plant lamps.

The next experiment was carried out in EC2 using ambient air in four stages. The first stage (E4) used one pot for 24 hours with one plant lamp. The second stage (E5) used six pots for 24 hours with one plant lamp. The third stage (E6) used six pots for 48 hours without any plant lamp. The fourth stage (E7) used six pots for 48 hours with a plant lamp on the first day and did not use a plant lamp on the second day (Fig.14).

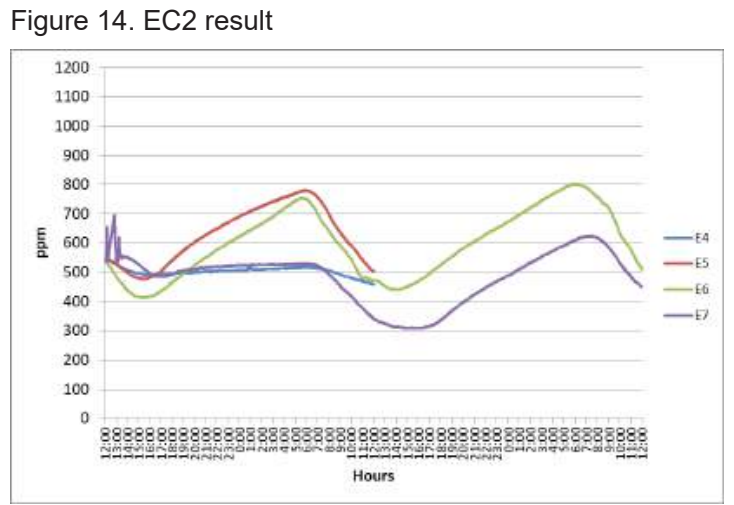

E4: One pot, 24 hours, with a plant lamp.

E5: Six pots, 24 hours, with a plant lamp.

E6: Six pots, 48 hours, without any plant lamp.

E7: Six pots, 48 hours, with a plant lamp on the first day. 
Table 4. Experiment Result

\begin{tabular}{|c|c|c|c|}
\hline Experiment & Time & $\begin{array}{c}\mathrm{CO}_{2} \\
\text { reduction } \\
(\mathrm{ppm})\end{array}$ & $\begin{array}{c}\mathrm{CO}_{2} \\
\text { increase } \\
(\mathrm{ppm})\end{array}$ \\
\hline \multirow[t]{3}{*}{ E1 } & $12.00-17.30$ & 300 & - \\
\hline & $17.30-07.00$ & - & 600 \\
\hline & $07.00-12.00$ & 520 & - \\
\hline \multirow[t]{3}{*}{ E2 } & $12.00-17.30$ & - & \\
\hline & $17.30-07.00$ & & 58 \\
\hline & $07.00-12.00$ & - & - \\
\hline \multirow[t]{3}{*}{ E3 } & $12.00-17.30$ & 359 & - \\
\hline & $17.30-07.00$ & - & 57 \\
\hline & $07.00-12.00$ & 105 & - \\
\hline \multirow[t]{3}{*}{ E4 } & $12.00-17.30$ & 55 & - \\
\hline & $17.30-07.00$ & - & 22 \\
\hline & $07.00-12.00$ & 54 & - \\
\hline \multirow[t]{3}{*}{ E5 } & $12.00-17.30$ & 70 & - \\
\hline & $17.30-07.00$ & - & 278 \\
\hline & $07.00-12.00$ & 252 & - \\
\hline \multirow[t]{5}{*}{ E6 } & $12.00-17.30$ & 134 & - \\
\hline & $17.30-07.00$ & - & 288 \\
\hline & $07.00-17.30$ & 242 & - \\
\hline & $17.30-07.00$ & - & 331 \\
\hline & $07.00-12.00$ & 281 & - \\
\hline \multirow[t]{5}{*}{ E7 } & $12.00-17.30$ & 61 & - \\
\hline & $17.30-07.00$ & - & 36 \\
\hline & $07.00-17.30$ & 199 & \\
\hline & $17.30-07.00$ & - & 299 \\
\hline & $07.00-12.00$ & 172 & - \\
\hline
\end{tabular}

Based on the results of the experiment for 24 hours and 48 hours, Dracaena sanderiana had a pattern in absorbing and releasing $\mathrm{CO}_{2}$. From morning to evening (07.00-17.30), it consumed $55 \mathrm{ppm}$ to $520 \mathrm{ppm}$ of $\mathrm{CO}_{2}$. At night (17.30-07.00), it released $22 \mathrm{ppm}$ to $600 \mathrm{ppm}$ of $\mathrm{CO}_{2}$. The use of plant lamps (a combination of the red and blue light) affected plants, $\mathrm{CO}_{2}$ released was less than without using plant lamps (E2, E4, E5, and E7 in Table 4). It shows there is a mechanism of $\mathrm{CO}_{2}$ absorption as an ingredient in the process of photosynthesis. Plants use light as an energy source for photosynthesis. Red color emits a narrow spectrum of light $(660 \mathrm{~nm})$ that is close to the maximum absorbance for both chlorophyll and phytochromes. The photosynthetic-mediated proteins in sub-compartments of chloroplasts, including stomatal opening and closing and photosynthetic activity, responded most to the blue of high light intensity (Muneer et al., 2014).
However, the absorption rate of $\mathrm{CO}_{2}$ in the morning was lower than when it was without a plant lamp (E2, E4, E5, and E7 in Table 4).

One of the factors that influence indoor $\mathrm{CO}_{2}$ concentrations is the number of indoor plants (Cetin, 2015). Based on the number of plants, in $\mathrm{E} 5$ that using six plants can decrease $\mathrm{CO}_{2}$ levels more than E4 that using one plant. The number of the plant can influence the chlorophyll index. The chlorophyll index is used to calculate the total chlorophyll content of the leaves. Chlorophyll is an essential part of the Calvin-Benson cycle, and it is responsible for harvesting light during photosynthesis, which results in the excitation of electrons that can continue to the photosynthesis process further to process the $\mathrm{CO} 2$ that has been absorbed (Ahlman, 2019).

Based on the experiment, a system to minimize stress on plants was derived. When the plant was forced to photosynthesize at night, it would decrease its $\mathrm{CO}_{2}$ absorption during the day. Therefore, to maximize $\mathrm{CO}_{2}$ absorption during the day, plants should be placed in areas that were connected or exposed to an outdoor environment. During the day, the plants were related to the interior of the building (Fig. 15), and at night the plants were in contact with the outdoor (Fig. 16). By doing so, the plants still obtained $\mathrm{O}_{2}$ at night and had the respiration process well. Therefore, during the day, the plants could absorb $\mathrm{CO}_{2}$ more optimal.

Figure 15. An example of the installation of Dracaena sanderiana in the room as a live air cleaner In the afternoon.

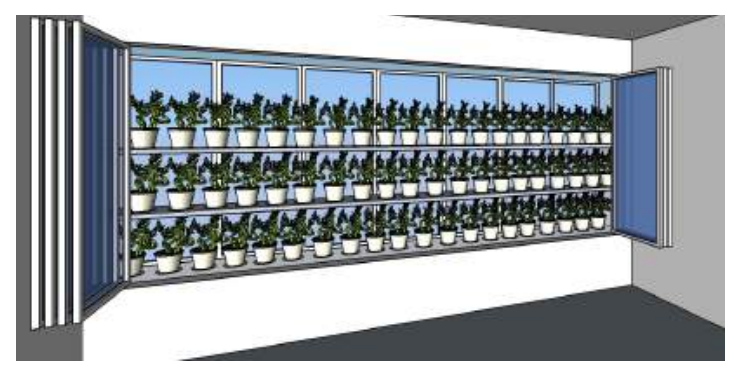

Figure 16. An example of the installation of Dracaena sanderiana in the room as a live air cleaner at night.

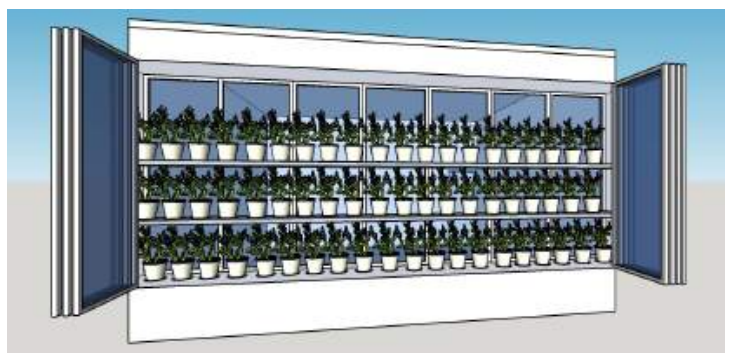


Figure 17. $\mathrm{CO}_{2}$ absorption during the day in $\mathrm{EC} 3$

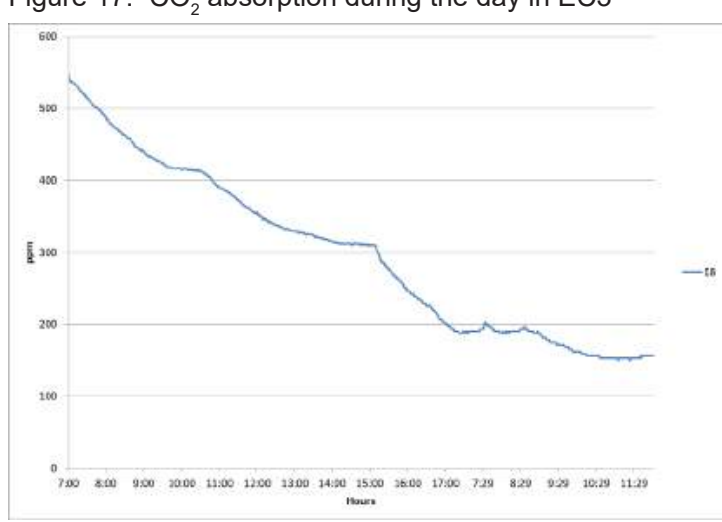

Figure 17 was a simulation when $\mathrm{CO}_{2}$ was given to the room (by spirits burning), and the plants did not release $\mathrm{CO}_{2}$ at night. However, when humans used the room, there was a difference, because humans produce $\mathrm{CO}_{2}$ continuously. So the use of Dracaena sanderiana was not to eliminate $\mathrm{CO}_{2}$ in the room (Fig. 18 and 19) but to prolong the time of human stay in the room based on the maximum limit of $\mathrm{CO}_{2}$ levels in the room which is $600-1000 \mathrm{ppm}$.

Figure 18. $\mathrm{CO}_{2}$ concentration on EC3with Human breath, facing north

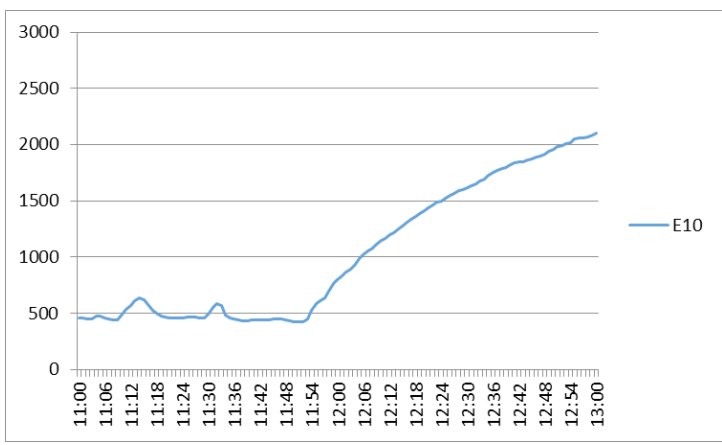

Figure 19. $\mathrm{CO}_{2}$ concentration on $\mathrm{EC} 3$ with Human breath, facing west

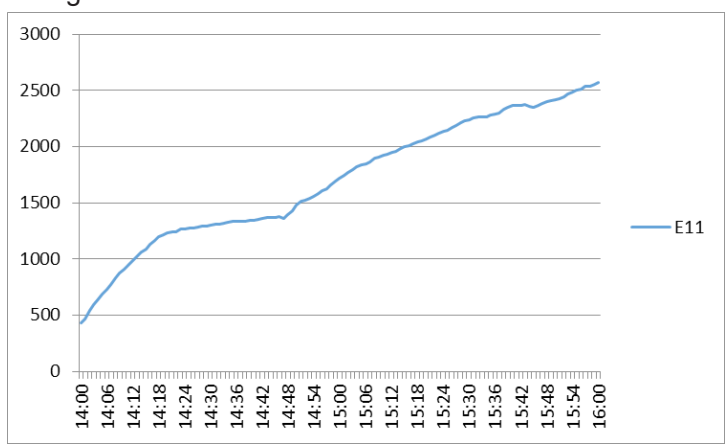

The length of time a human stays in the room can be calculated as follows:

Human breath composition (Marieb and Hoehn, 2013)

$$
\begin{array}{ll}
\text { - Exhale } & : 4 \% \mathrm{CO}_{2} \\
\text { - Inhale } & : 0.04 \% \mathrm{CO}_{2} \\
& (1 / 100 \text { exhale - ignore })
\end{array}
$$

Breathing process

- 1 breath cycle : 0.5 liter

$$
\text { : } 0.5 \times 4 \%=0.02 \text { liter }
$$

- 1 minute : $6-18$ times breathing (average $17 x$ ) : 0.02 liter $x 17=0.34$ liter $/$ minute

- Conversion to ppm

$0.02 \mathrm{l} / \mathrm{breath}$.minute in $1 \mathrm{~m}^{3}$

$0.02 \mathrm{l} / \mathrm{breath}$.minute in $1000 \mathrm{I}$

- $(20 \mathrm{ml} /$ breath $\cdot$ minute $) / 1000.000 \mathrm{ml}=20 \mathrm{ppm} /$ breath.minute

- $20 \mathrm{ppm} /$ breath.minute $\times 17$ breath $=340 \mathrm{ppm} /$ minute

- Initial level = CO2 of normal outdoor air is

400 ppm

- Danger limit $=1,000 \mathrm{ppm}$

- Maximum $=(1000-400) \mathrm{ppm}=600 \mathrm{ppm}$

(in $1 \mathrm{~m}^{3}$ )

(1 room with $36 \mathrm{~m}^{3}$ )

$$
=600 \mathrm{ppm} \times 36 \mathrm{~m}^{3}=21.600 \mathrm{ppm}
$$

- Absorption capability of one group of plants in $0.063 \mathrm{~m}^{3}\left(612 \mathrm{~cm}^{2}\right.$ leaf surface area $)=92.25 \mathrm{ppm} /$ hours, in $1 \mathrm{~m}^{3}=6 \mathrm{ppm} /$ hours and $0.17 \mathrm{ppm} /$ hours in $36 \mathrm{~m}^{3}$

- Human $\mathrm{CO}_{2}$ production $=340 \mathrm{ppm} \cdot \mathrm{m}^{3} /$ minute $=20.400 \mathrm{ppm} \cdot \mathrm{m}^{3} /$ hours

Level of $\mathrm{CO}_{2}$ indoor (for a room with volume $36 \mathrm{~m}^{3}$ ):

- Human production of $\mathrm{CO}_{2}=9.44 \mathrm{ppm} /$ minutes

- Length of breathing to $\mathrm{CO}_{2}$ limit $=566.4 \mathrm{ppm} / \mathrm{hours}$

$=21.600 \mathrm{ppm} / 566.4 \mathrm{ppm} / \mathrm{hours}$

$=38.1$ hours (limit $1000 \mathrm{ppm}$ in the room)

- With 50 units of plants $=21.600$ ppm / (566.4-

8.5) $\mathrm{ppm} / \mathrm{hrs}$

$$
=21.600 \mathrm{ppm} / 557.9
$$

$\mathrm{ppm} / \mathrm{hrs}$

$$
=38.7 \mathrm{hrs}
$$

- Length of stay in the room $=(38.7-38.1) \mathrm{hrs}$ $=36$ minutes (thus Dracaena sanderiana adds the length of stay 36 minutes)

The above calculation shows that before using Dracaena sanderiana, humans can stay 38.1 hours nonstop, but after using Dracaena sanderiana, they can stay 38.7 nonstop. Dracaena sanderiana can prolong the human stay in $36 \mathrm{~m}^{3}$ of space for 36 minutes.

\section{Conclusion}

Dracaena sanderiana can absorb $\mathrm{CO}_{2}$, but its efficiency is low. It has the potential of a live air cleaner. However, considerable quantities of Dracaena sanderiana are needed if significant $\mathrm{CO}_{2}$ removal from a room is wanted. It means a large proportion of floor area should be dedicated to those plants, which is not space- 
efficient. Vertical racks can be provided to stack the pots to save space. With its much lower $\mathrm{CO}_{2}$ absorption than human $\mathrm{CO}_{2}$ production, Dracaena sanderiana is intended to reduce, not remove, $\mathrm{CO}_{2}$. In other words, it is used to delay the $\mathrm{CO}_{2}$ concentration limit of $1,000 \mathrm{ppm}$ and thus prolong the stay time of humans in a healthier room. Dracaena sanderiana performs photosynthesis at night and releases large amounts of $\mathrm{CO}_{2}$. Thus, during the day, the plants can be connected to the interior of the building to absorb $\mathrm{CO}_{2}$, and at night they can be connected to the outdoor to release their $\mathrm{CO}_{2}$. It will neither interfere with the process of photosynthesis nor the process of respiration.

\section{Recommendation}

Dracaena sanderiana has, like other plants, a unique nature, which should be well understood through further studies. This research was deliberately experimenting with Dracaena sanderiana in its natural condition. There was no biological engineering applied to Dracaena sanderiana to improve its $\mathrm{CO}_{2}$ absorption efficiency, such as giving special nutrition. Therefore, there are topics for further studies on Dracaena sanderiana as well as other potential plants.

\section{Acknowledgment}

This research was funded by the Ministry of Research and Technology of Indonesia through the Higher Education-Leading Applied Research scheme and Universitas Atma Jaya Yogyakarta under contract number 117/HBPEN/LPPM/V/2019.

\section{Reference}

Ahlman, L., Bånkestad, D. and Wik, T. (2019). "Relation between Changes in Photosynthetic Rate and Changes in Canopy Level Chlorophyll Fluorescence Generated by Light Excitation of Different Led Colours in Various Background Light," Remote Sens., 11, 434; DOI:10.3390/ rs11040434. pp 1-19

Bulgurcu, H., Ilten, N. and Cosgun, A. (2006). "Indoor air quality problems and solutions in schools," Journal of Installation Engineering. 96, 59.

Burchett, M. (2009). “Towards improving indoor air quality with pot -plants - A multifactorial investigation," Sydney.

Burchett, M., Torpy, F and Tarran, J. (2008).
"Interior plants for sustainable facility ecology and workplace productivity," ... '08-Enabling Sustain.

Cetin, M. (2015). "Determining the bioclimatic comfort in Kastamonu city," Environ. Monit. Assess. 187 (10), 640.

Holding, D. R. and Streich, A. M. (2013). "Plant Growth Processes: Transpiration, photosynthesis, and respiration," Board Reagents Univ. Nebraska.

Llewellyn, D and Dixon, M. (2011). "Can Plants Really Improve Indoor Air Quality?," in Comprehensive Biotechnology, Second Edition.

Marieb, E. N. and Hoehn, K. (2013). "Mechanics of Breathing: Pulmonary Ventilation," in Human Anatomy and Physiology, pp. 817819

Muneer, S., Kim, E. J., Park, J. S. and Lee, J. H. (2014). "Influence of Green, Red and Blue Light Emitting Diodes on Multiprotein Complex Proteins and Photosynthetic Activity under Different Light Intensities in Lettuce Leaves (Lactuca sativa L.)," Int. J. Mol. Sci., 15, 4657-4670; DOI:10.3390/ ijms15034657. pp 4657 - 4670.

Soreanu, G., Dixon, M. and Darlington, A. (2013). "Botanical biofiltration of indoor gaseous pollutants - A mini-review," Chemical Engineering Journal.

Stanke, D. A., et al. (2010). "Ventilation for acceptable indoor air quality," ASHRAE Stand., vol. 2007, no. STANDARD 62.1, pp. 1-70.

Su, Y.-M. (2014). "CO2 Purify Effect on Improvement of Indoor Air Quality (IAQ) Through Indoor Vertical Greening," in Transactions on Engineering Technologies.

Suhaimi, M. M., et al. (2017). "Effectiveness of Indoor Plant to Reduce CO 2 in Indoor Environment," MATEC Web Conf.

Tarran, J., Torpy, F and Burchett, M. (2007). "Use Of Living Pot-Plants To Cleanse Indoor Air - Research Review," in Proceedings of Sixth International Conference on Indoor Air Quality, Ventilation \& Energy Conservation in Buildings - Sustainable Built Environment, Oct 28-31, 2007, Sendai, Japan.

Wood, R. A., Burchett, M. D., Alquezar, R., Orwell, R. L., Tarran, J. and Torpy, F. (2006). "The potted-plant microcosm substantially reduces indoor air VOC pollution: I. Office field-study," Water. Air. Soil Pollut. 